\title{
The Serbian Diaspora's Political Views: A Study on the 2017 Serbian Presidential Election
}

Tena Prelec

School of Law, Politics and Sociology, University of Sussex, UK

\begin{abstract}
Members of the Serbian diaspora, especially those who were vocal in representing their home country's views, have previously been regarded as leaning towards nationalistic stances. The results of recent elections, however, indicate that today a rather different situation might be present among the diaspora, as voters abroad have started to choose predominantly non-nationalistic options at the ballot box, preferring candidates with a progressive agenda. This study confirms this indication. The analysis sheds light on the political views of Serbian citizens abroad, discussing the results of two surveys conducted around the Serbian presidential elections held in April 2017. Three main sets of findings concerning the attitudes of the 'active diaspora' (i.e. diaspora members who took part, or wanted to take part, in the voting process) are outlined. First, there is a stark opposition to the government in power and a decisive rejection of the course the country has taken. Second, it is shown that concerns about governance (corruption, labour market, and education) top by far geopolitical issues such as Kosovo, relations with Russia, and EU accession. Finally, respondents have highlighted a wide-ranging set of issues concerning the voting procedure, which have hindered their ability to participate in the vote. Here they are used as a basis to formulate recommendations for a better electoral process for the diaspora. The overall findings indicate that Serbia's active diaspora might have the potential to participate more vigorously in the political life of the country and that, if emboldened, its weight in future elections could be much higher.
\end{abstract}

\section{Introduction}

Approximately one in ten Serbs live abroad: the latest data from the International Organization for Migration ${ }^{1}$ put the 'stock' of outward migration from Serbia at 964,585 , noting that 9.8 percent of all citizens of Serbia live outside their country of origin. Other unofficial estimates quote an even higher number, putting the number of Serbian citizens living abroad at totals ranging between 2-3 million. ${ }^{2}$ This is, in any case, a large contingent, when compared to a population of about 7 million living in Serbia. ${ }^{3}$ Out of these, only 9,523 Serbs abroad made use of their right to vote in the 2017 presidential election. Why this gap? What are the current political views of the diaspora, and what can be done to further stimulate their engagement? This paper addresses these questions through a study carried out during the 2017 presidential vote. It will be argued that, while a level of disaffection with the political processes in the country of origin is only natural for citizens living abroad, this large gap is likely to be partially accounted for by the difficulties experienced during the registration process. Concerning the political stances of the diaspora, this study highlights that - contrary to previously held beliefs a majority of the politically active members of the diaspora (i.e. those who were intentioned to take 
part in the voting process) do not show great interest for topics that are usually linked to nationalistic stances, while expressing the highest concerns over governance issues. Pooling responses from over 300 members of the Serbian diaspora, the study furthermore suggests a number of practical actions which can be carried out in order to increase the political participation of the diaspora. An open question remains as to the presence of the political will to implement such relatively simple changes, which could have a considerable impact on future elections.

\section{Literature review: previous studies on diaspora's political views and the need to move the research agenda forward}

Members of diasporas have long been perceived to have more extreme views than the locals - i.e. those who have stayed in the home country - after a war. So far, migration dynamics from the Balkan countries have been mostly looked at through this post-conflict lens. That diaspora members hold more radical political views is indeed a widespread assumption in the literature on migration, and well beyond South-East-Europe, ${ }^{4}$ though it is not one that has been supported by solid empirical findings. The explanations upon which this postulation rests range from the need to maintain a collective identity in the face of a new, alien territory ${ }^{5}$ or to preserve myths and political ideologies; ${ }^{6}$ to the radicalisation that occurs in neighbouring countries, where 'temporary' camps may become permanent $;{ }^{7}$ or to the fact that locals may be incentivized to compromise and forge a common life, ${ }^{8}$ while migrants would become polarized because of the lack of contact with an adversary. ${ }^{9}$ In a nutshell, the assumption is that ' $[R]$ emembering a conquered or oppressed home is one of the duties of emigrants; the problem is that exile can freeze conviction at the moment of departure. Once in exile, groups fail to evolve'. ${ }^{10}$

The diasporas from the Western Balkans have very often been associated with precisely these dynamics; something that has been accentuated by the disproportionate attention that the scholarship on the region has given to war and conflict. And while these insights should be kept in mind, this line of inquiry urgently needs to be complemented by fresh thinking. A recent study by Jonathan Hall, comparing the views and attitudes of Bosnians who have stayed in their country with those who left in the 1990s, found out that migrants do not necessarily hold more extreme views than those who stayed. ${ }^{11}$ Analysing data from simultaneous surveys conducted in the two countries, Hall's research showed that, under certain conditions, migrants can benefit from opportunities for reconciliation and assimilation offered by the recipient country, and that in such cases their views can indeed become more conciliatory than those of their peers who stayed in the home country. Another recent study ${ }^{12}$ highlighted the positive experience of Bosnian refugees in three countries out of the four considered, signalling once again the importance of investigating the effect of the policies of the recipient countries on migrants' attitudes. ${ }^{13}$

This paper confirms that this novel trajectory is an important one, and worth exploring further. Its findings corroborate the need to problematize this key assumption in the literature on migration and the Western Balkans. It will be shown that a significant part of the Serbian diaspora - specifically, the higher educated segments of the population who have moved abroad in more recent times and who make up the majority of the country's politically active diaspora, i.e. who take an interest in the home country's political and electoral process - do not fit in the above-mentioned categorization of hard-liners unable to evolve their views. Quite the contrary, these individuals belong to a category of 
people who are unhappy with the autocratic direction taken by their government, and hold diametrically opposed views to those espoused by the country's leadership.

Clearly, the discrepancy between the key assumption discussed above (that migrants hold more extreme views than their peers who stayed in the home country) and the more recent works disproving it, is partially to be sought in a change in migration patterns, which have ostensibly taken a different nuance in more recent times. The lack of economic prospects, and even more the lack of a level playing field in the home country, is making many young people leave the Western Balkans, with very grave consequences at present - and potentially detrimental consequences in the future for the economic, social and political fabric of those countries. This is something that requires a robust new research agenda. It is thus long overdue to abandon the lens of war and conflict to explain the migration dynamics concerning Balkans.

\section{The 2017 presidential vote and the diaspora}

Data collection was carried out in conjunction with the 2017 Serbian presidential election. The vote took place on 2 April, ${ }^{14}$ with a hypothetical run-off initially foreseen for two weeks later. The voting process abroad was fraught with hastiness, communication issues and physical barriers. The registration process for the diaspora was announced on 3 March on the website of the Ministry of Foreign Affairs of Serbia ${ }^{15}$ and voters had eight days, i.e. up until 11 March, to sign up. Polling stations were opened only in places where at least 100 voters had registered. Postal voting was not allowed, and voters were compelled to cast their ballots in the same place in both rounds: this made it impossible for those travelling to Serbia for Easter holidays to express their preference in a hypothetical run-off, which was scheduled to happen on Easter Sunday - but ended up not taking place due to Aleksandar Vučić's victory in the first round. As a result, only 53 voting stations were opened worldwide, and 11,590 Serbian citizens abroad registered to vote, with merely 9,523 people

casting their ballots on voting day. ${ }^{16}$ No voting stations were opened in a number of key diaspora countries - Australia being just one case in point (see Figure 1). Figure 2 shows in more detail the voting stations in Europe. 
Figure 1. Diaspora voting stations worldwide

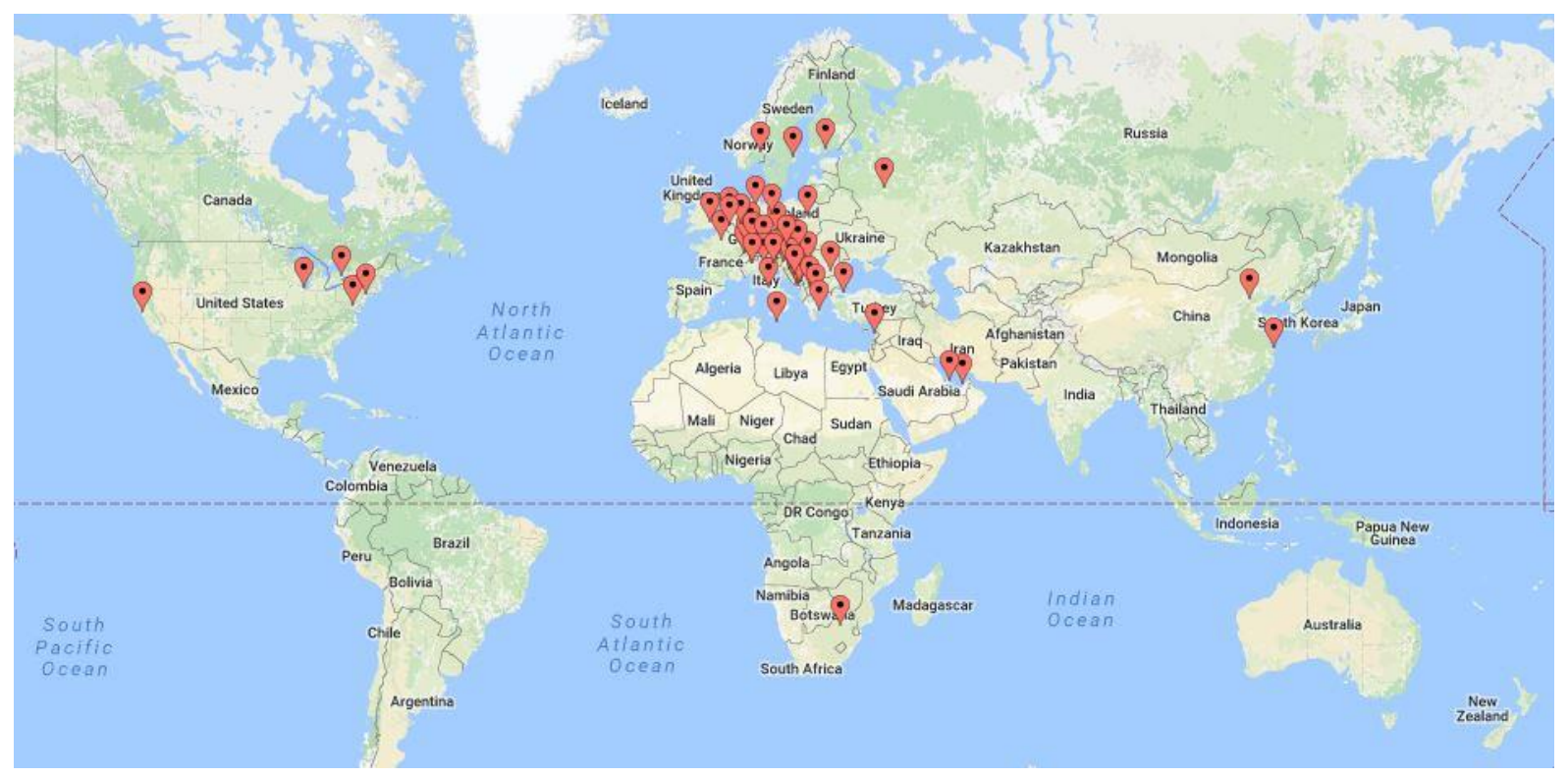

Figure 2. Diaspora voting stations in Europe

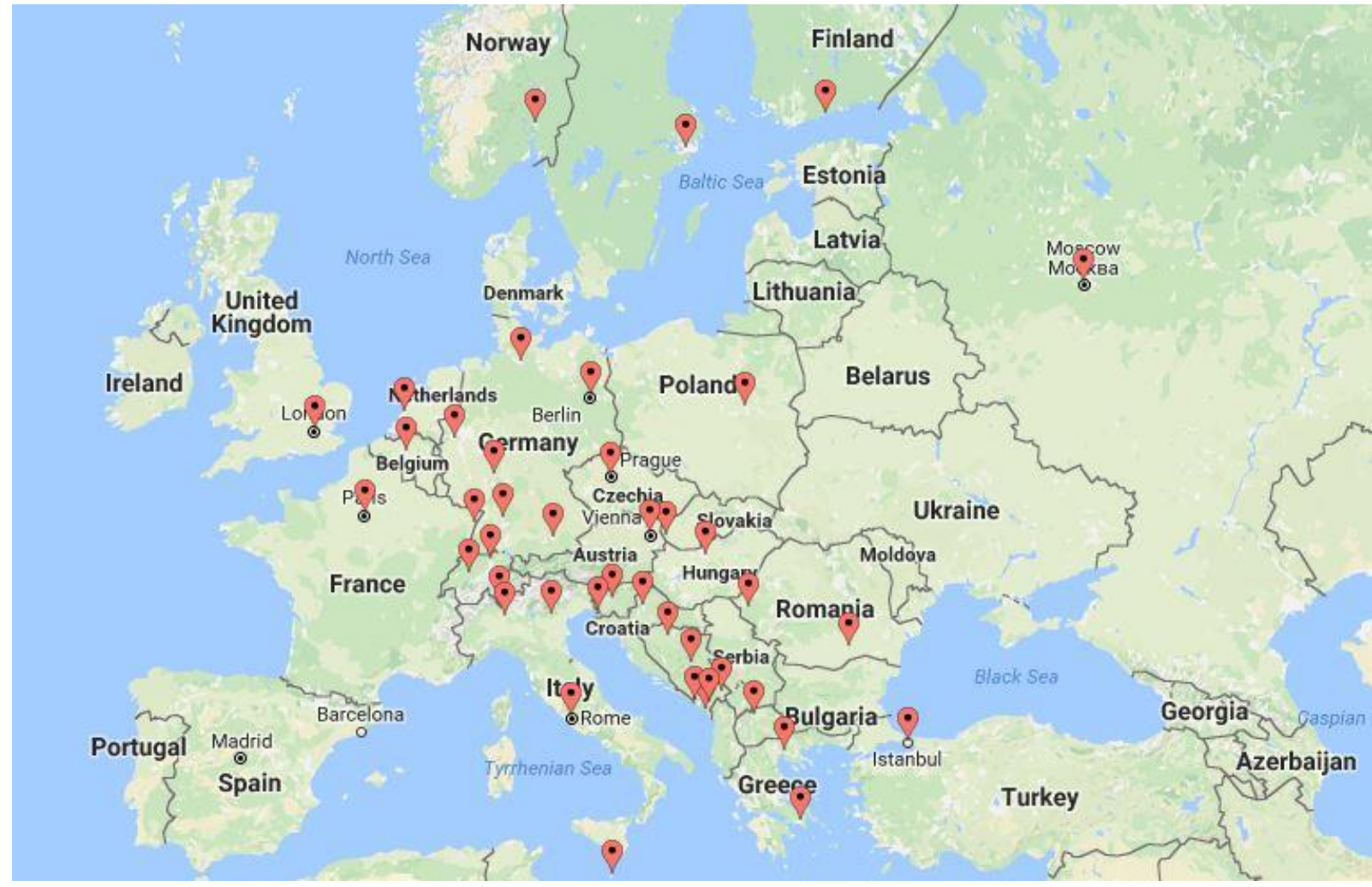

Source: RIK (Serbian Electoral Committee). Compiled by the author. The interactive map can be accessed at: http://bit.ly/SerbianDiasporaVotingStations2017 


\section{The runners and riders and the outcome}

A short note about the most prominent of the 11 candidates is in order. Aleksandar Vučić, the overall winner of the election - who was, at the time of the vote, the incumbent Prime Minister and leader of the Serbian Progressive Party - decided to stand for the presidency after internal polling showed that the outgoing President and co-party member, Tomislav Nikolić, would risk losing the contest. A nationalist in his youth, hailing from Vojislav Šešelj's Radical Party and having served as Minister of Information under Slobodan Milošević, Vučić had successfully carved an image of a man who juggles a pro-European agenda while still representing the national interests of Serbia. His style of government is unmistakeably top-down, concentrating the decision-making in his hands and monopolising media attention ${ }^{17}$ - features that did not change in his passage from Prime Minister to President. He was the clear frontrunner from the beginning.

Several new challengers from different strands of the opposition had also thrown their hats in the ring: former Ombudsman Saša Janković, former Foreign Minister and UN General Assembly President Vuk Jeremić, comedian Luka Maksimović (running as the spoof candidate Ljubiša 'Beli' Preletačević), and Enough is Enough leader Saša Radulović. Other challengers included Vojislav Šešelj of the nationalist Radical Party, and Boško Obradović, who heads the far-right movement 'Dveri'. The campaign was therefore an exceptionally lively one, with large rallies and the parody candidate 'Beli', who entered the contest at a late stage, gaining very significant traction in the last weeks of the campaign and ending in third place.

The result of the diaspora vote, however, indicated a reversed outcome: there was a marked preference for the opposition candidate Saša Janković (Figure 3), while the ballots for Vučić were almost halved in comparison to the overall outcome. Janković represented a broad progressive platform that appealed mostly to city-dwellers. ${ }^{18}$ His candidate pitch highlighted European and liberal values and denounced what he referred to as 'bratija', literally 'brotherhood', meaning the informal network of favours that, as he maintains, has taken the place of the state. ${ }^{19}$ Similar messages were pushed by Saša Radulović, Vuk Jeremić and (in a reverse fashion) by the comedian Maksimović. 
Figure 3. Serbian presidential election outcomes - overall vote and diaspora vote compared

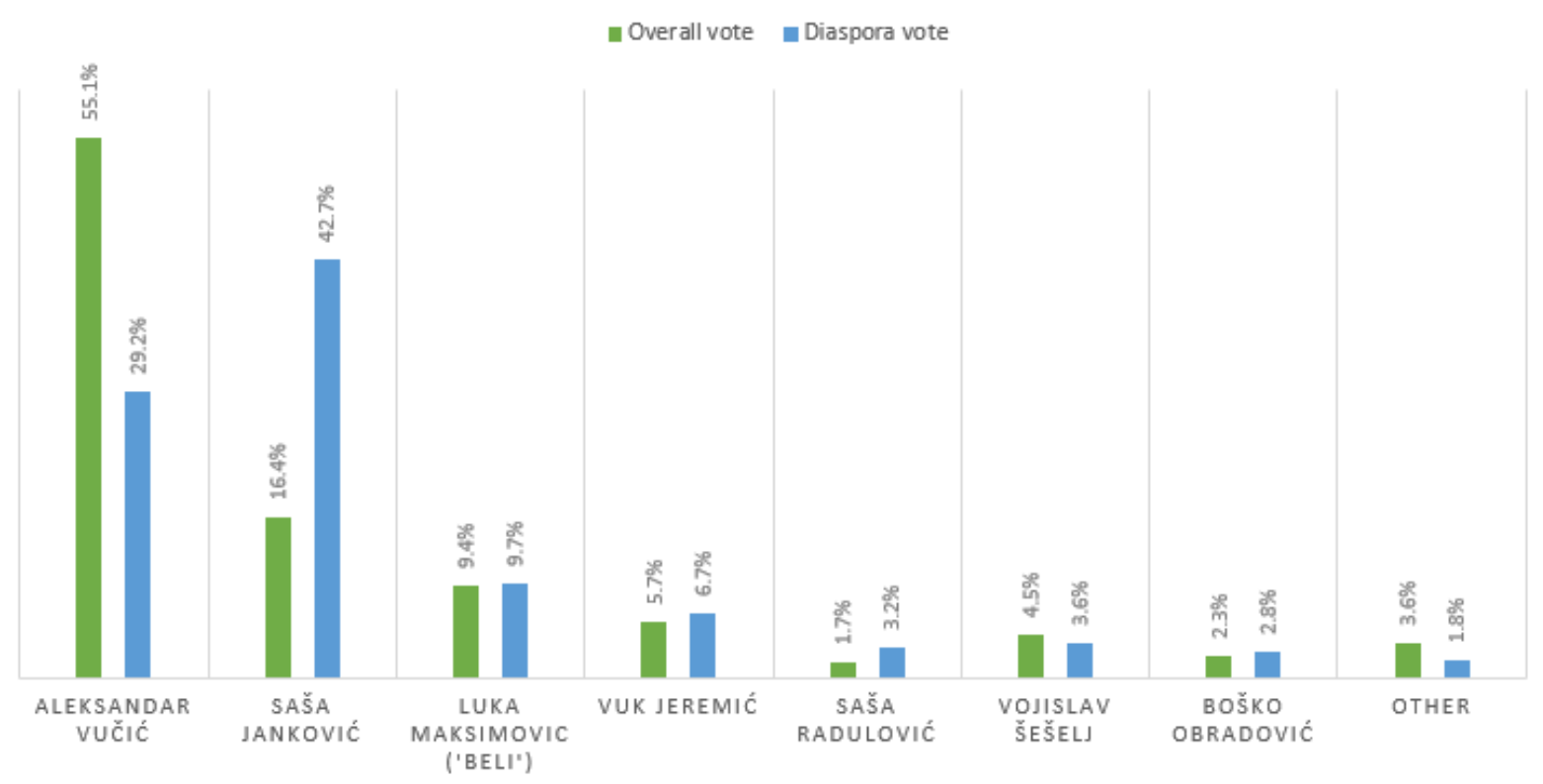

Source: RIK (Serbian Electoral Committee)

\section{The surveys}

To understand better the political attitudes of this potentially large but understudied contingent of voters - the Serbian diaspora - I created a first pre-electoral survey (Survey 1), distributed in the week before the vote (25 March-1 April 2017). ${ }^{20}$ Survey 1 was shared with individuals and closed diaspora groups, rather than publishing the link more widely. Aside from basic demographic questions, respondents were asked to identify their current country and city of residence; how long ago they moved to Serbia; what source(s) of information they use when learning about Serbian politics; what were their voting intentions for the 2 April 2017 presidential election and for a hypothetical run-off; what they thought were the voting intentions of their relatives and friends abroad and in Serbia; whether the electoral campaign impacted their opinion of the presidential candidates; whether they were satisfied with the voting procedure for Serbs above and why; what were, according to them, the key issues in Serbia today; and what was their overall opinion of the Serbian government.

A further follow-up survey (Survey 2), focusing on the views of the diaspora on political engagement, was circulated among Survey 1 respondents after the election. ${ }^{21}$ This survey collected more in-depth, qualitative responses on their current involvement in political activism; on their propensity to get involved in civic and political movements in (or on) Serbia; on their thoughts about returning to Serbia one day; and on what they see as the role of the Serbian diaspora and whether the diaspora should take part in the economic, political and social developments at home.

Considering the groups and individuals from whom the surveys started to be disseminated, I expected the immediate snowballing effect to have reached especially the higher-educated strata of the Serbian diaspora population. The education level of the respondents was indeed very high, with almost $70 \%$ in possession of a Master's degree or a $\mathrm{PhD}$ (Figure 4). 


\section{Figure 4. Highest level of education completed}

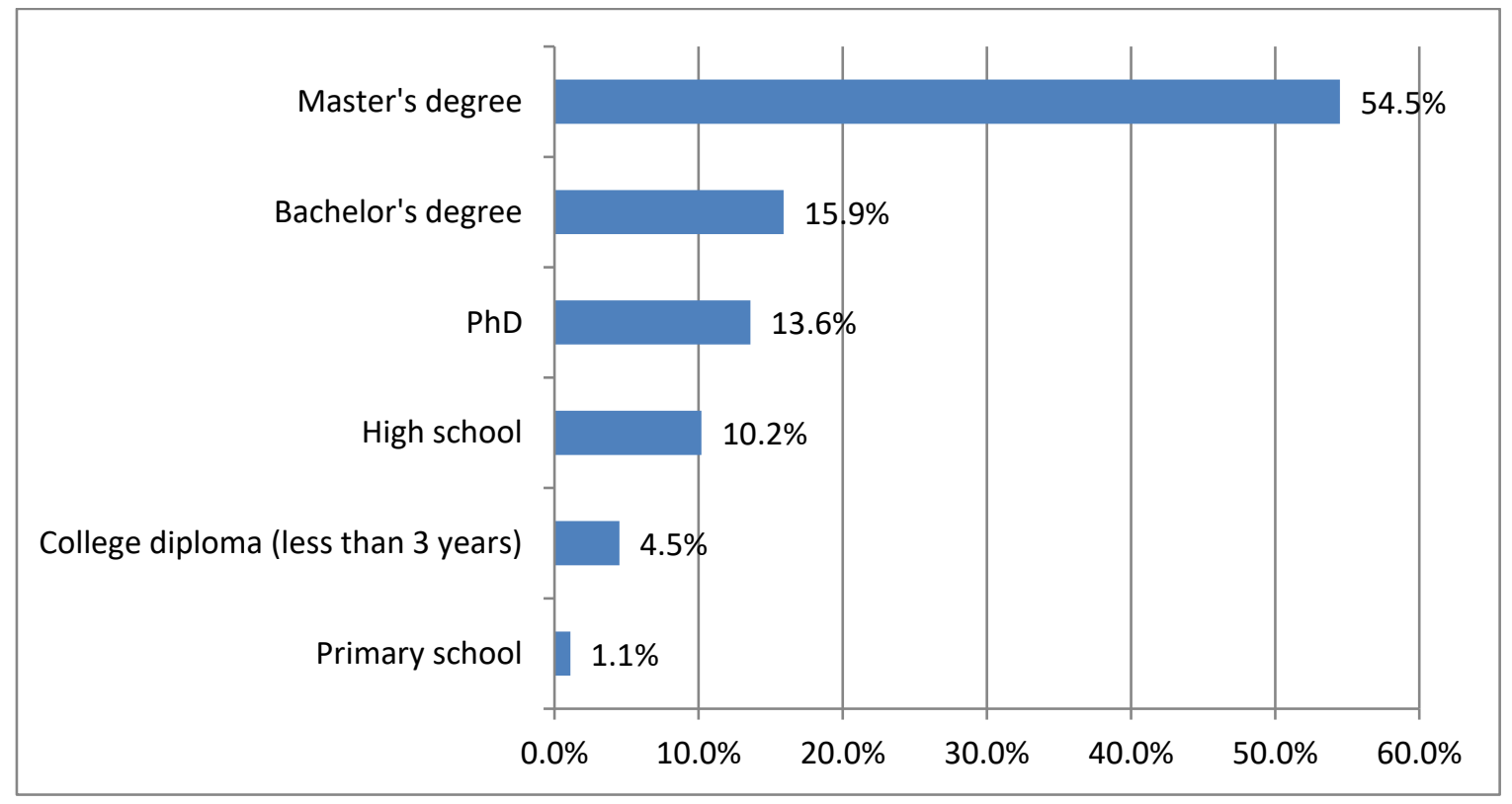

Source: Survey 2

I therefore attempted to correct for these foreseen biases by pro-actively contacting respondents who are part of more traditional or nationalistic-leaning groups, reaching out to communities linked to the Serbian Church, and even by flagging the survey up to diaspora groups of the Serbian Progressive Party. Even so, the results obtained in terms of voting preferences (which have largely matched the eventual outcome), show a widespread rejection of the current government, and of Aleksandar Vučić in particular, among the diaspora members surveyed. ${ }^{22}$

The surveys achieved good geographic coverage, collecting responses from respondents living in 47 countries; and the overall sample $(\mathrm{N}=322)$ is significant, if set against the number of registered voters $(11,590)$. Out of the 47 countries, the main ones were as follows (with the number of respondents in brackets): Germany (52), UK (37), Austria (24), Italy (20), UAE (19), USA (17), France (15), Norway (15), Switzerland (14), the Netherlands (12), Sweden (9), and Canada (8). ${ }^{23}$

\section{Opposition to the government}

The most striking response regards the opinion of the current Serbian government: over 71 percent of our respondents chose to tick the 'very negative' box (Figure 5), and a further 21.1 percent opted for 'negative'. These stark figures were echoed by verbal entries in the questionnaire surveys; some examples follow. ${ }^{24}$ 
Figure 5. What is your overall opinion of the Serbian government at present?

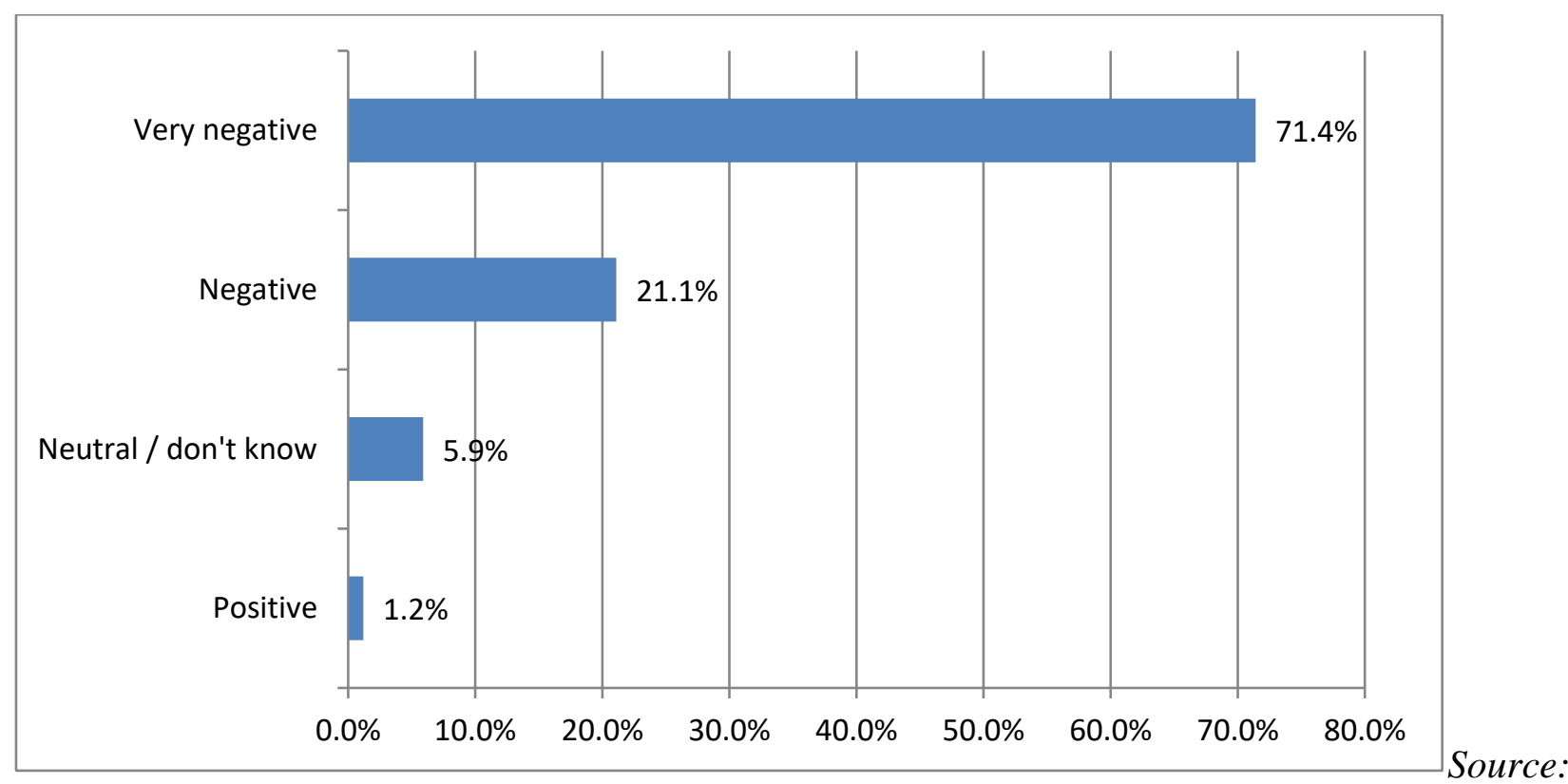

Survey 1 .

First, only a few respondents defended Aleksandar Vučić's work:

I started following Serbian politics with the rise of Vučić. He is the only candidate that I can follow because he is discussing relevant issues, the economy!!! Everyone else is always involved in some kind of name calling and revolution.

Or expressed mixed opinions:

Vučić gets my points for understanding the importance of both Germany/the West and Russia. One should not be forsaken for the other and a good politician should be able to play both sides. He understands the importance of PR and media for his own gains and the country's image abroad. He is a better politician than all of the other candidates but he has become a modern dictator, oppressing people by controlling the media.

But most of the respondents expressed a strong desire for renewal and markedly negative opinions of the government, as the following typical entries attest:

We need to build a new system. A new society. We do not have time nor strength for the [further] implementation of something which is deviant in substance - the result will always be the same.

There are many of us who would like to come back and invest in Serbia. To do so, we need strong institutions and a State that works. Most of us have left because we felt like secondrate citizens in our own country. Let's start from a radical change of the taxation system and the judiciary.

Dictatorship. The Serbian Third Reich is upon us if we do not bring Vučić down. 
The moment when the current government came to power has been decisive in my decision to leave Serbia. I realised then that I cannot stay in my own country.

Particracy and autocracy are destroying us.

[The government is] criminal, totalitarian, incompetent, immoral, shameless, corrupt, not fit for purpose.

\section{A new cleavage?}

The above-described desire for a radical renewal, and opposition to the current course taken by the Serbian political scene, is not entirely unusual: it finds its most recent echo in the almost month-long protests on the streets of several Serbian cities that followed the 2 April election. ${ }^{25}$ Survey 1 respondents were asked to indicate who they think their friends abroad and those in Serbia were going to vote for. It was expected that a much higher number of responses in favour of Aleksandar Vučić would be ticked in this case, but this was only marginally so: 24 out of 322 respondents thought that their acquaintances in Serbia were going to vote for Vučić, 7 that their friends abroad would do so. This seems to point to the fact that members of the diaspora are connected with like-minded people at home. The election has therefore exposed the increasingly clearer profiling of two distinct groups within Serbian society - one outward facing that is critical of the government, and a more traditional and rural one - interacting very little with one another. One of the key discriminants may well be the media: while television and print are the main sources of information at home, a total of 93 percent of respondents indicated that their preferred channel of information about Serbian politics is the web (Figure 6), with 47.1 percent opting for social media and 45.3 percent choosing online publications.

Figure 6. Where do you predominantly get your information on Serbian politics from?

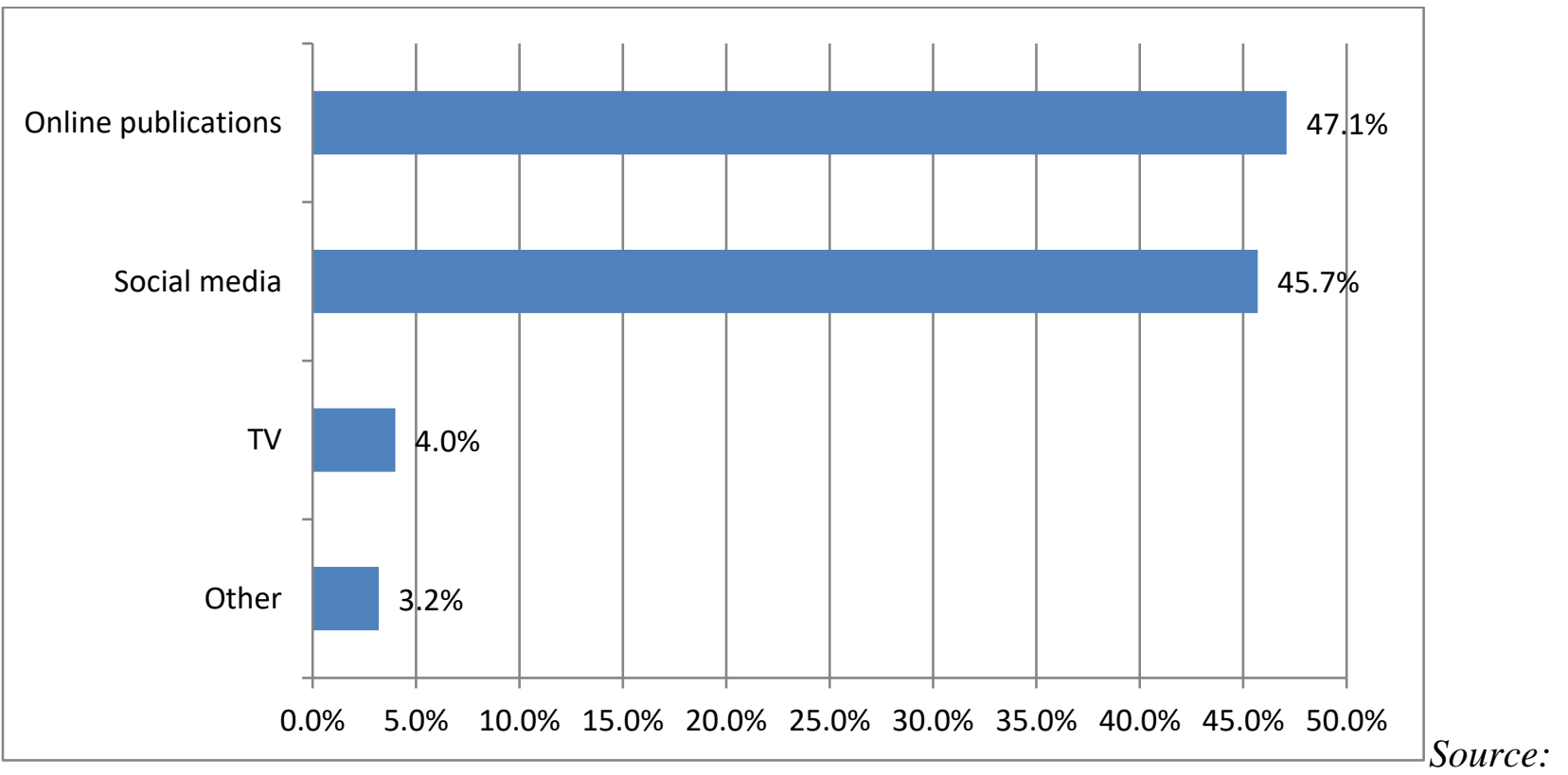

Survey 1. 


\section{Concerns: governance over geopolitics}

The survey responses shed further light on the main concerns harboured by the active diaspora. In contrast to previously-held beliefs on the nationalistic stances of the Serbian diaspora actively representing Serbia's voice abroad, ${ }^{26}$ these responses indicate that the trend has now changed. The issues of Kosovo, of Serbia's relations with Russia and even with the EU, are lowest on the list. Concerns about governance, on the contrary, fare highest: corruption takes the first spot, followed by the judiciary, media freedom, autocracy, education, access to the labour market and economic inequality. As Figure 7 shows, all the above issues are highlighted by at least $70 \%$ of the survey respondents, ranging up to $88 \%$ on the issue of corruption. All other issues polled responses of less than $50 \%$.

\section{Figure 7. What are some of the key issues in Serbia today?}

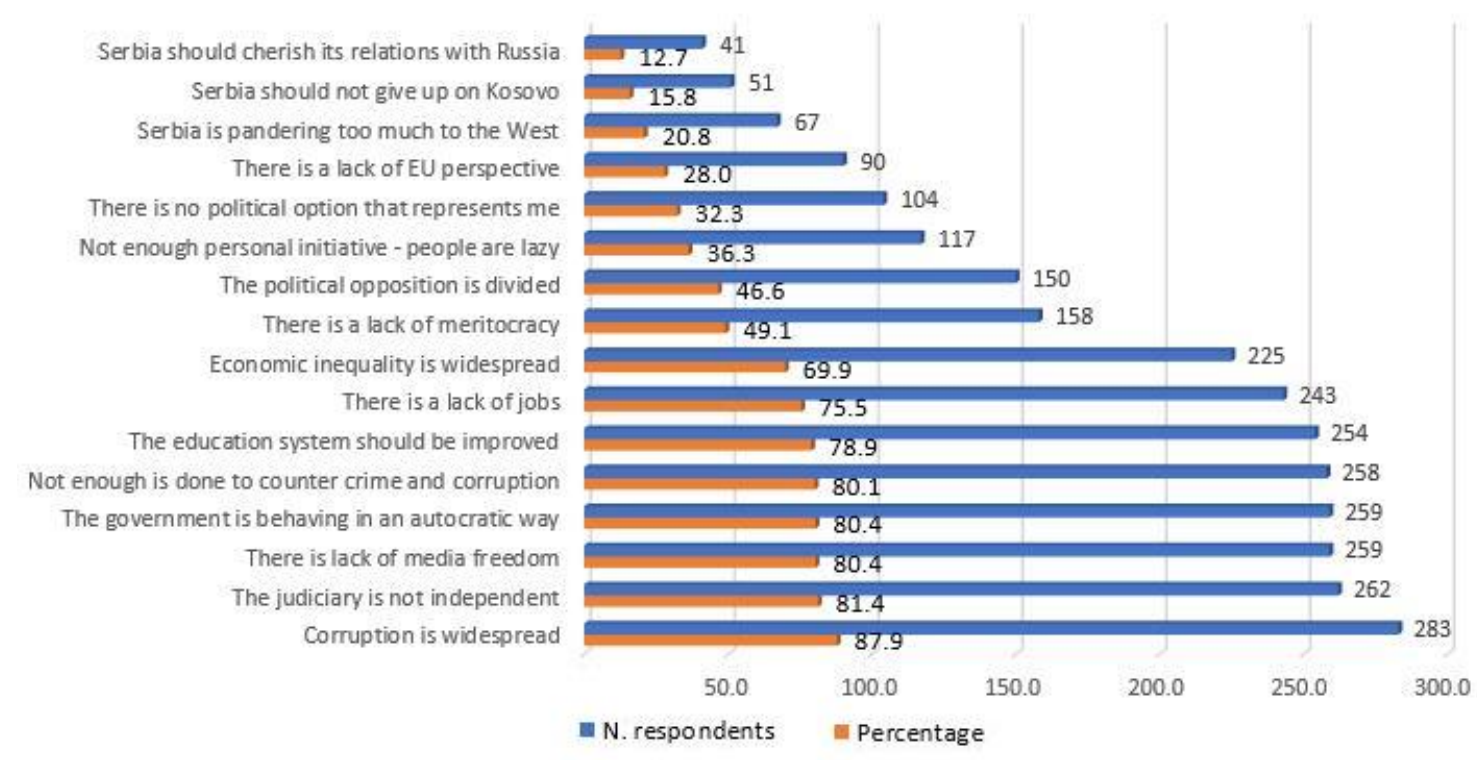

Source: Survey 1.

\section{Barriers to the vote}

Many of the respondents lamented that certain aspects of the voting procedure for the diaspora made it difficult for them to participate in the process, and a great many complained that they were unable to vote, despite a desire to do so. The registration itself, while not entirely straightforward, ${ }^{27}$ did not present excessive difficulty. ${ }^{28}$ The most widespread problems however were: 1) short notice: voters abroad were given only one week to register for the vote; 2) communication: effective communication was lacking - many citizens were not informed or informed late; 3) scarcity of voting stations: the rule that at least 100 voters should have registered to open a voting station meant that in many cases people who lived far away from the main cities could not vote, and in many countries no voting stations were present whatsoever; and 4) IT issues (server failures) in embassies and consulates that have jeopardised the registration of voters in more than one city. Furthermore, the need to vote in the same place in both rounds (with a hypothetical run-off taking place on Easter day) would have precluded the vote for all those who had travel plans for the Easter holidays. The experience of Ugljesa Grušić, a law lecturer at University College London (UK), is illuminating in this sense: ${ }^{29}$ 
I will be in Serbia during the first round and in London during the second round of the election. I emailed the embassy to ask whether I could register to vote in London in the run-off. The embassy replied that they received a 'notification' from the Ministry of Foreign Affairs stating that it is not possible to change the voting location after the first round. I replied to this email quoting Article 23 of the Law on a Single Electoral Roll, the Constitution and the European human rights instruments. I asked them to send me the text of the instruction and to justify their refusal to allow me to exercise my voting right. I received the following reply (my translation): 'Unfortunately, we cannot send you the original text of the notification that we received from the Ministry of Foreign Affairs, since it is part of official communication between the Ministry and the Embassy, but we posted this information on the website'. Needless to say, I felt infuriated and totally powerless when I saw this reply. I feel that there is nothing I can do about this. Serbia is at the moment a country where the constitution and the laws can be suspended by a 'notification' issued by a Government ministry, which notification no one is able to see.

\section{Going forward: how can Serbia empower its diaspora?}

How to right these wrongs, and improve the diaspora's political participation? Responses collected through Survey 2 indicate four main ways to achieve this. It should be noted that not all respondents were of the opinion that increased political participation of members of the diaspora should be pursued. In the words of one of them: 'I left my country and have no right to meddle in the fate of the people living there. We are all the victims of our choices. Most individuals, however, were keen to think of ways to increase their participation, and several of them held a strong opinion in this sense: 'Diaspora members keep Serbia afloat with their remittances. We therefore have full moral right to participate in the political process'.

By far, the most quoted remark concerned the access to the electoral process, highlighting the need to implement a more efficient system - as outlined above. Implementing postal and electronic voting was consistently mentioned as a necessary development to guarantee voting rights for diaspora members. A second aspect raised is the issue of representation in parliament at general elections. Contrary to what takes place in some neighbouring countries (Croatia is a case in point), the diaspora is not given direct representation in parliament. Furthermore, an oft-quoted remark was that embassies and consulates should step up their game in providing a helpful service to Serbs abroad. Complaints were raised mainly in relation to the voting process (informing citizens and guaranteeing their right to vote), but many suggested that the diplomatic bodies should do more to provide occasions for Serbs to get together and organize. To increase the organization of diaspora members, respondents furthermore suggested setting up social media groups, non-profit organisations and websites for the diaspora. It should be noted that, while there is no overarching organisation, a few such spontaneous groups already existed, and some were set up specifically for the 2017 presidential elections - such as Glasajmo and Dijaspora Glasa. ${ }^{30}$

Many highlighted that they would be happy to share their skills and knowledge with their compatriots, and a clear majority of respondents said they would at least consider returning to Serbia. Most of them, however, set out quite clear conditions under which they would return. The most quoted motivation was achieving financial freedom, to be able to be free from political influences. As a close 
second, respondents quoted fair competition (meritocracy) as a necessary precondition, making reference to the economic and political situation and advocating the end of corruption and 'particracy'. The concern regarding the society where their children will be growing up was a drawback in this sense: parents with young children quoted this as a reason to stay abroad. Few respondents showed enthusiasm towards returning and participating in the life of the country as it stands and, finally, personal motivations (of a non-political nature) were quoted as well. It is clear, however, that the political and economic situation in the country - perceived as unjust - was the top concern of the respondents. One individual summarized this by stating: 'As long as corruption and the disregard for rules are present in all spheres of life, I am not thinking about a return to Serbia'.

The insights above show that the political situation back home has the distinct ability to influence the willingness of this class of diaspora voters to remain in their home country, to return to it, and to engage with the political and social developments of the places of origin. This finding is corroborated when assessing the aftermath of the change in the Macedonian government in May 2017, which occurred after a long stalemate and through the engagement of both civil society movements and relevant EU institutions. The grass-root protests were triggered by the discovery, in February 2015, of widespread government-sponsored illegal surveillance, and leaked tapes exposed the extent to which the state was being captured by a corrupt, authoritarian and self-serving elite. ${ }^{31}$ Elections in December 2016 resulted in a change in voters' preferences, and eventually in the appointment of a new government. There is, for now, anecdotal evidence that the democratic election of a new reformist government, which represented a change of guard after over ten years, is directly linked with a shift in the attitude of young people towards migration. ${ }^{32}$ After a decade of heavy brain drain, Macedonian youth is now 'not so sure that they want to leave the country any longer', while the new government 'wants to move things forward, but they find it very difficult to find appropriate cadres because of the heavy brain drain that occurred previously'. ${ }^{33}$ The brain drain, of course, does not need to be necessarily negative: the impact of returnees on the home country has been shown to be extremely positive. ${ }^{34}$ The question is, therefore, how to make best use of the social capital and to feed it back in. It is also a very urgent research question: as the quote above shows, if we have to wait for too long, there will be no one left in the country to carry out a progressive and transparent agenda when the opportunity is presented.

\section{Conclusions}

The study outlined in this paper has focused on the political participation of the Serbian diaspora in Serbia's 2017 presidential election. It has concentrated on the views of what has been termed 'active diaspora': individuals living abroad who have taken a clear interest in the home country's electoral process. The research points to the importance of a heavily under-researched topic - the changing views of portions of the Balkan diasporas, the obstacles to their engagement and avenues for their future participation - and it has the ambition to open the door to a number of research questions that are, I would argue, extremely meaningful. Some of the findings highlight glaring deficiencies in the voting process for Serbs abroad that require prompt and decisive action, and should be of interest to policy-makers. ${ }^{35}$

The main findings can be expressed in three sets. First, the active diaspora is strongly opposed to authoritarianism and is widely critical of (Prime Minister and then) President Vučić. 
The stance of the active diaspora has been shown to be overwhelmingly opposed to the current direction of travel of the political leadership of their country. While this is clear from the result of the diaspora vote itself, the qualitative material collected and analysed above shows the vehemence with which such convictions are held.

Second, the active diaspora deeply cares about governance issues, disregarding topics linked to international relations and to nationalistic stances. Governance (corruption, judiciary, press freedom, employment, and education) comes first among the worries of the survey respondents. The very little importance given to issues such as EU accession, relations with Russia and, especially, the question of Kosovo, challenges previously held beliefs that Serbia's diaspora is nationalistic. While it cannot be denied that clubs and associations with more traditional views exist abroad, this study has shown that the politically active members - many of whom have moved abroad more recently - are not bothered by these topics. This seems to corroborate the findings by Efendic et al., who remark that individuals with a higher level of education, and with a stable employment status, are less sensitive to the issue of ethnicity. ${ }^{36}$ It is also potentially interesting insofar as it diverges from the political views of neighbouring countries' diasporas, namely the Croatian one ${ }^{37}$ which is viewed as holding particularly nationalistic views. ${ }^{38}$ Furthermore, most of the surveyed individuals appear to be connected to like-minded individuals at home. Respondents indicated that their family and friends in Serbia will be voting for opposition candidates. This suggests the profiling of two groups not along a left-right divide, but rather along a cleavage which is located on a pro- and anti-government axis. Therefore, two groups interacting very little with each other seem to be profiling themselves within Serbian society: one outward-facing that is critical of the government and that includes mostly city dwellers and a majority of the members of the active diaspora, and a more traditional and rural one. Initial interviews with Serbian activists corroborate this finding, ${ }^{39}$ but further research is needed to test these remarks.

Finally, the results presented in this paper show that the political participation of the diaspora is currently heavily hindered and has space for growth. The responses collected and analysed recommend a number of uncontroversial 'quick wins' that the government could implement relatively easily starting from the next elections: the implementation of the postal vote; a longer time frame for registrations and an easier registration process; improved communication and better service from embassies and consulates; and making sure there are no IT problems that prevent the registration of voters. Other suggestions are slightly more problematic, but should be taken into account and discussed openly: electronic voting; the parliamentary representation for voters abroad; and the full listing of Serbs living abroad.

On a whole, the findings indicate that Serbia's active diaspora has the potential to participate more vigorously in the political life of the country and that, if emboldened, its weight in future elections could be much higher. From a long-term perspective, it is clear that the way to incentivize the participation of the active diaspora in political and economic processes in Serbia is to foster a higher level of equality and meritocracy in the Serbian society - an insight that finds corroboration in the shifting attitudes of Macedonians after the democratic change of their government's leadership in 2017, when they are reported to have become less keen to emigrate. The question that remains, however, is whether it is in the interests of Serbia's ruling elite to act upon these insights and allow for a pool of increasingly cosmopolitan and progressively-minded citizens to take a more active part in domestic politics. Acting upon the recommendations presented in this paper, i.e. taking concrete 
steps to remove barriers to the diaspora vote, would be the best way to dispel any doubts that these restrictions to political participation are maintained to further their own electoral scopes.

\section{Acknowledgements}

The author would like to thank the many Serbian diaspora groups and individuals that have enthusiastically contributed to the dissemination of the survey, as well as the LSE's EUROPPEuropean Politics and Policy Blog (edited by Dr Stuart Brown) for providing an early avenue for discussion.

\section{Disclosure statement}

No potential conflict of interest was reported by the author.

\section{Funding}

Economic and Social Research Council (ESRC) - grant number: ES/J500173/1

\section{Notes on contributor}

Tena Prelec is completing her PhD in the school of Law, Politics and Sociology at the University of Sussex. She is also a Research Associate at LSEE-Research on South Eastern Europe, European Institute, London School of Economics and Political Science.

\section{Notes}

1 Source of data is International Organization for Migration, https://www.iom.int/countries/serbia and https://www.iom.int/world-migration (accessed 23 January 2018).

2 See https://en.wikipedia.org/wiki/Serb diaspora (accessed 23 January 2018).

3 V. Ilić, 'Nevolje sa biračkim spiskom', Peščanik, 15 April 2017. http://pescanik.net/nevolje-sa-birackim-spiskom/ (accessed 23 January 2018).

4 See: B. Anderson, 'Long distance nationalism.' In B. Anderson (ed.) The Spectre of Comparisons: Nationalism, Southeast Asia and the World, Verso, London, 1998, pp. 58-74; M. B. Anderson, Do No Harm: How Aid Can Support Peace-or War, Lynne Rienner, Boulder (CO), 1999, p. 18; B. Bigombe, P. Collier, and N. Sambanis, 'Policies for building post-conflict peace.', Journal of African Economies, 9 (3), 2000, pp. 333-334; B. Bock-Luna, The Past in Exile: Serbian Long-distance Nationalism and Identity in the Wake of the Third Balkan War. Transaction Publishers, New Brunswick, NJ, 2007; P. Collier and A. Hoeffler, 'Greed and grievance in civil war', Oxford Economic Papers, 56 (4), 2004, pp. 563-595; P. Collier and A. Hoeffler, 'The political economy of secession', in H. Hannum and E. F. Babbitt (eds) Negotiating Self-Determination, Lexington Books, Lanham, MD, 2006, pp. 37-59; G. Golan and A. Gal, 'Globalisation and the transformation of conflict', in B. W. Dayton and L. Kriesberg (eds), Transformation and Peacebuilding: Moving from Violence to Sustainable Peace, Routledge, New York, 2009; M. Ignatieff, 'The hate stops here', The Globe and Mail, 25 October 2001, https://www.theglobeandmail.com/opinion/the-hate-stops-here/article763813/ (accessed 14 January 2018); M. Kaldor, New and Old Wars: Organised Violence in a Global Era. Polity Press, Oxford, 2001; J. Kaldor-Robinson, 'The virtual and the imaginary: the role of diasporic new media in the construction of a national identity during the break-up of Yugoslavia'. Oxford Development Studies, 30(2), 2002, pp. 177-187; T. Lyons, 'Diasporas and homeland conflict'. In Globalization, Territoriality, and Conflict, edited by M. Kahler and B. F. Walter, Cambridge University Press, Cambridge, 2006, pp. 111-132; T. Lyons. 'Conflict-generated diasporas and transnational politics 
in Ethiopia'. Conflict, Security, and Development, 7 (4), 2007, pp. 529-549; D. Newman. 'The resilience of territorial conflict in an era of globalization' in Territoriality and Conflict in an Era of Globalization, edited by M. Kahler and B. F. Walter. Cambridge University Press, Cambridge, 2006, pp. 85-110; Y. Shain. Kinship and Diasporas in International Affairs. Ann Arbor: University of Michigan Press, 2007; S. Turner. 'The waxing and waning of the political field in Burundi and its diaspora' Ethnic and Racial Studies, 31(4), 2008, pp. 742-765; A. Wennmann. 'The political economy of conflict financing: a comprehensive approach beyond natural resources'. Global Governance, 13(?), 2007, pp. 427-444.

5 A. Smith, The Ethnic Origins of Nations, Blackwell, Oxford, 1986.

6 Lyons, op. Cit.; Turner, op. cit.

7 H. Adelman, 'Why refugee warriors are threats', The Journal of Conflict Studies, 18(1), 1998, pp. 49-69.

$8 \quad$ Collier and Hoeffler, op. cit.

9 Turner, op. cit.

10 Ignatieff, op. cit.; Bock-Luna, op. cit.

11 J. Hall, 'Are migrants more extreme than locals after war? Evidence from a simultaneous survey of migrants in Sweden and locals in Bosnia', Journal of Conflict Resolution, 60(1), 2016, pp. 89-117.

12 M. Barslund et al., Labour Market Integration of Refugees: A comparative survey of Bosnians in five EU countries, CEPS Special Report No. 155, 9 December 2016.

13 It has been impossible to properly address this specific question in this paper due to the lack of enough countryspecific data, for which there is the need for a much more ambitious - and better resourced - data collection process.

14 In certain cities outside of Serbia (London, Toronto, Washington DC, Chicago, New York and San Francisco), diaspora members voted on 1 April 2017.

15 Serbian Government, MFA (Office for the collaboration with the diaspora and with Serbs in the Region) - The vote from abroad http://www.dijaspora.gov.rs/lat/glasanje-iz-inostranstva/ (accessed 23 January 2018).

16 RIK (Serbian Electoral Committee) - Results of the 2017 Presidential Election http://www.rik.parlament.gov.rs/izbori-za-predsednika-republike-2017-konacni-2004.php (accessed 23 January 2018).

17 Media analysis agency Kliping found that an astonishing 51 per cent of air time dedicated to the 2017 presidential elections was dedicated to Aleksandar Vučić, and the figure increases to 67 per cent when including his appearances as prime minister http://www.danas.rs/izbori.1180.html?news id=342219\&title=Apsolutna\%20dominacija\%20Vu\%C4\%8Di\%C4\%8 7a\%20na\%20TV (accessed 23 January 2018). The message conveyed by Vučić's campaign through a TV spot was that Serbia could not be governed by two pilots - implying that he would be keeping the helm in the future as well.

18 V. Ilić, 'Igrajmo se zanimljive izborne geografije u Srbiji', VICE Serbia, 2 May 2017. Available at: https://www.vice.com/rs/article/igrajmo-se-zanimljive-izborne-geografije-u-srbiji (accessed 23 January 2018).

19 Blic, 'Janković: Potrebna nam je država, a ne bratija', Blic, 15.02.2017. https://www.blic.rs/vesti/politika/jankovic-potrebna-nam-je-drzava-a-ne-bratija/z7dk8e4 (accessed 23 January 2018).

20 Survey 1. Serbian diaspora - Presidential elections 2017. Online survey conducted by the author on 25 March-1 April 2017. Respondents were Serbian adult citizens living abroad. $N=322$. Full data available in private archive.

21 Survey 2. Serbian diaspora 2017 - Follow-up. Follow-up online survey conducted by the author on 2-7 May 2017. Respondents were a random selection of respondents to Survey $1 . \mathrm{N}=83$. Full data available in private archive.

22 T. Prelec, 'Voters are split between two distinct groups: pro- and anti-Vučić', in 'Experts react: Aleksandar Vučić wins Serbia's presidential election', LSE EUROPP - European Politics and Policy, 3 April 2017. Available at: http://blogs.Ise.ac.uk/europpblog/2017/04/03/experts-react-aleksandar-vucic-wins-serbias-presidentialelection/\#Four (accessed 23 January 2018). 
23 Responses were furthermore collected from the following countries: Australia, Belgium, Bosnia and Herzegovina, Bulgaria, Croatia, Cyprus, Czech Republic, Denmark, Estonia, Faroe Islands, Finland, Greece, Hong Kong, Hungary, Iceland, Indonesia, Ireland, Israel, Luxembourg, Malta, Mexico, Monaco, Montenegro, Poland, Portugal, Qatar, Romania, Russia, Singapore, Slovakia, Slovenia, South Korea, Spain, Thailand, and Turkey.

24 The quotes are selected for their generally typical and representative nature.

25 The Editorial Board, 'A Serbian Election Erodes Democracy', The New York Times, 9 April 2017. https://www.nytimes.com/2017/04/09/opinion/a-serbian-election-erodes-democracy.html (accessed 23 January 2018).

26 Bock-Luna, op.cit.

27 See this graph by twitter user Filip Perisic: 'How to fight for your voting rights if you live abroad' https://twitter.com/OnlineTulip/status/837800761983664130 (accessed 23 January 2018).

28 Glasajmo Iz Inostranstva - Facebook page: https://www.facebook.com/GlasajmolzInostranstva/; Twitter page: https://twitter.com/glasajmo (accessed 23 January 2018).

29 Email interview with the author, 23 March 2017. Private archive.

30 Dijaspora Glasa - Facebook page: https://www.facebook.com/dijasporaglasa/?ref=br rs (accessed 23 January 2018).

31 T. Prelec, 'The Macedonian surveillance scandal that brought down a government', Computer Weekly, June 2017. http://www.computerweekly.com/feature/The-Macedonian-surveillance-scandal-that-brought-down-agovernment (accessed 25 April 2018).

32 Expert speaker at the roundtable on 'The UK and the Future of the Western Balkans', International Relations Committee, UK House of Lords, 17 January 2018. (Event held under Chatham house rules). This issue - how attitudes towards emigration have changed among Macedonian citizens in the aftermath of the government's change - is a clear potential avenue for future research.

33 Ibid

34 R. Crescenzi, N. Holman and E. Orru', 'Why do they return? Beyond the economic drivers of graduate return migration', The Annals of Regional Science, 59, 2017, p. 603.

35 These issues resonate with the problems encountered in recent times by several diasporas from South Eastern Europe, e.g. by Romanians and Bulgarians (in the latter case, a campaign by members of the diaspora has resulted in a partial improvement of the voting regulations): it is clear that this is not only a Serbian problem, and a comparative analysis would be extremely welcome.

36 A. Efendic, B. Babic, and A. Rebmann., Social capital, migration, ethnic diversity and economic performance: a multidisciplinary evidence from South Eastern Europe, Research brief, CISAR: Sarajevo. http://rrppwesternbalkans.net/en/News/Research-brief-Social-Capital--Migration--Ethnic-DiversityLmainColumnParagraphs/0/text files/file/Research-Brief-Social-capital-A5-ENG-WEB.pdf (accessed 23 January 2018).

37 S. Carter, 'The geopolitics of diaspora', Area, 37(1), 2005, pp. 54-63.

38 However, further research needs to be done on the views of the Croatian diaspora as well, considering the very high number of young Croats who have left the country to work in other EU countries in the last years. It is highly likely that the composition of the diaspora has changed, and their political views with it.

39 The movement Ne Davimo Beograd have stated that approximately 75 percent of their acitivists have either had an experience abroad or are currently enrolled in a study programme abroad. Interview by the author with coordinators of the 'Ne Davimo Beograd' movement. Belgrade, 12 April 2017, and follow-up via email. 